\title{
Analysis of Optimal Portfolio Performance Comparison on Companies Listed in LQ45 Index and Companies Unregistered in LQ45 Index
}

\author{
I Gusti Bagus Yosia Wiryakusuma \\ International Business Management, Ciputra University, Surabaya, Indonesia
}

Corresponding Author:

I Gusti Bagus Yosia Wiryakusuma

bagus.yosia@ciputra.ac.id

Received: 30 December 2019

Accepted: 29 January 2020

Published: 6 February 2020

Publishing services provided by Knowledge E

(c) I Gusti Bagus Yosia

Wiryakusuma. This article is

distributed under the terms of

the Creative Commons

Attribution License, which

permits unrestricted use and

redistribution provided that the

original author and source are credited.

Selection and Peer-review under the responsibility of the 6 th ICOEN 2019 Conference Committee.

\section{S OPEN ACCESS}

\begin{abstract}
This research was conducted based on the increase in society's enthusiasm towards investing in the capital market, particularly the stock market. New investors' lack of knowledge about stock may lead them to invest in stocks only based on the return. Return is one of the most important factor in choosing stock to invest in, however it is not the only important factor. Investors should also consider the stock's risks as well as whether the stock is very high in volatility or not (Shares with high volatility is called "saham gorengan" in Indonesian). The purpose of this research is to find out the differences between optimal portfolio which consists of stocks registered in LQ45 Index and optimal portfolio which consists of stocks unregistered in LQ45 Index within the time frame of 2015-2017. The research method used is t-test to differentiate two means from two independent samples. The finding of this research shows there is a significant difference between optimal portfolio which consists of stocks registered in LQ45 Index and optimal portfolio which consists of stocks unregistered in LQ45 Index within the period of 2015-2017.
\end{abstract}

Keywords: Markowitz's portofolio, lq45 index, t-test, return, risk

\section{Introduction}

In the past few years, the capital market has been significantly developing, one of them is Indonesia's capital market. There are many government programs that encourages the society to invest which have been well received by most of the public. Investing is an act of allocating some funds with the goal of gaining profit in the future (Tandelilin, 2010:2). Investing has the goal of obtaining profit at the moment as well as in the future. In investing, investors are expected to have understood investment concepts which are the basis of decision making process in investing. Investors are expected to also have understood the investment instrument to be used. 
One of the investing instruments that are widely used is stock investment. Stock can be defined as one's or an institution's sign of ownership (Darmadji dan Fakhruddin, 2012;5). Investing in stock can present high return, in fact, there are several stocks that have high return growth up to $200 \%$ within one year. However, with the high return, certainly high risk follows. In Indonesia, there are stocks called "saham gorengan", which are high volatility stocks. These type of stocks can provide even higher return within hours, however the risks are also much higher. Moreover, if the investor makes the wrong move, tremendous loss is guaranteed. A part from high volatility stocks, there are other stocks registered in the LQ45 Index.

LQ45 Index is an index listing 45 most liquid stocks which have high capitalization (Setiawan, 2017). In contrast to high volatility stocks, stocks registered in LQ45 Index cannot provide return as high as the return of high volatility stocks within a short period, however they provide return that gradually grows with lower risks.

Risks in investing cannot be eliminated, rather they can be minimalized. Building an optimal portfolio can be used to reduce risks. One of the models to build portfolio is using Markowitz Model. Using Markowitz Model, a combination of stocks for an optimal portfolio can be identified. Furthermore, the proportion of fund needed to be allocated for each stock can be identified as well. Markowitz Model can also calculate the expected risk and the return of the portfolio.

Stocks registered in the LQ45 Index are the most liquid stocks in Indonesian stock exchange, therefore can be considered as the most favorite stocks. In addition, these stocks can be liquidize easier compared to other stocks. In this research, the data used are stocks registered in the LQ45 Index within the period of 2015-2017 and stocks unregistered in LQ45 Index within the period of 2015-2017 which are considered to have the highest return in its own sectors.

Based on the discussion above, therefore the title of this research is "ANALYSIS OF OPTIMAL PORTFOLIO PERFORMANCE COMPARISON ON COMPANIES LISTED IN LQ45 INDEX AND COMPANIES UNREGISTERED IN LQ45 INDEX"

\section{Theoretical Foundation}

\subsection{Capital Market}

Capital market is a place where various financial instruments are traded, such as money, equity (stock), and other instruments (Darmadji dan Fakhruddin, 2012:1). Capital market can be defined as a place for security trading which the securities in general have more 
than one year of maturity, such as stock and bonds (Tandelilin, 2010:26). Capital market enables optimum fund allocation. Capital market can also become the alternative of investing a part from investment in property. There are various investment instruments that can be traded in the capital market, such as stocks, bonds, rights, warrant, mutual funds, etc.

\subsection{Stock}

Stock is defined as one's or an institution's sign of ownership (Darmadji dan Fakhruddin, 2012;5). Stock explains the ownership of the company issuing the stocks (Natalia, Darminto, dan Endang, 2014). The portion of ownership in a company is determined by how much stock is owned by an individual or an institution. Stockholder has the rights to vote in various important decision making in the company. Stockholder also has the rights to claim the earning as well as the asset of the company (Tandelilin, 2010:32).

\subsection{Return and Risk}

Return of stock is consist of capital gain (loss) and dividend yield. Capital gain (loss) is the difference between selling and buying price of a stock divided by the buying price of the stock, capital gain happens when the selling price is higher than the buying price, whereas capital loss happens when the selling price is lower than the buying price. Dividend yield is dividend distributed to the stockholders, dividend per share divided by the buying price per share (Zubir, 2013:4). Systematically, stock return can be written as follows

$$
\text { Return = capital gain (loss) }+ \text { dividend yield }
$$

Where,

$$
\text { Capital gain (loss) }=\frac{\text { selling price-buying price }}{\text { buying price }}
$$

Risk is the difference between the expected return and the actual return received. (Tandelilin, 2010:103). To calculate risk of a stock, the stock's variance and standard deviation are calculated.

Return and risk of a stock have a positive correlation, the more return, thus the more risk. Vice versa, the lower the return, the lower the risk. It can be seen that stocks registered in LQ45 Index approximately have lower return with comparable lower risk. Vice versa, high volatility stocks with high return also have high risks. 


\subsection{Portofolio Theory}

Risk cannot be avoided, all investment instruments have their own risks. Even though risk cannot be avoided, it can be reduced. Portfolio aims to reduce the risk of an investment. In a portfolio, the investor invest one's capital in various stocks. The capital is then allocated to several stocks with certain compositions to reduce risks. The investor will choose the stock composition which can generate the highest return/profit with the lowest possible risks.

\subsection{Markowitz Model}

One of the most commonly used portfolio model is Markowitz Model. By using Markowitz Model, stocks that build an optimal portfolio can be identified. In addition, the proportion of fund needed to be allocated for each stock can also be identified. Markowitz Model can provide the calculation of the expected risks and return of the portfolio.

\subsection{Coefficient of Variation}

In choosing investment, there are several things to be closely considered, including the risks and expected return of the investment (Jogiyanto, 2009). Coefficient of variation is a ratio of risk divided by expected return. Systematically, the formula of coefficient of variation can be written as follows:

$$
\text { Coefficient of Variation }=\frac{\text { Risk }}{\text { Expected Return }}
$$

Higher coefficient of variation states that the risk of the investment is higher than the return. Lower coefficient of variation thus means the return of the investment is higher compared to the risks. The lower the coefficient of variation the better the investment.

\section{Research Method}

This research is a comparative descriptive research, which studies the performance of an existing portfolio and the comparison between the performances of portfolio consists of stocks registered in LQ45 Index and portfolio consists of stocks unregistered in LQ45 Index. Data gathering technique used is secondary data of stock price within a certain period, which is $2015-2017$. This research used data from stocks registered subsequently 
in LQ45 Index in 2015-2017 and these stocks have the highest return in their own sectors. A part from that, this research also used data from stocks unregistered in LQ45 Index and these stocks have the highest return in their own sectors. This research is divided into two stages, the first stage is to build the portfolio from stocks registered in LQ45 Index and stocks unregistered in LQ45 Index.

\subsection{Building Optimal Portofolio}

When building a portfolio, use the Markowitz Model. Below are the stages of building an optimal portfolio using Markowitz Model:

1. Calculate the return from the stock price

2. Calculate the risk of the company

3. Calculate the covariance among the stocks

4. Calculate correlation coefficient among stocks

5. Calculate the expected return of the portofolio

6. Calculate the risk of the portofolio

To test the difference between the two portfolios, coefficient of variation of the existing portfolios are needed. After the value of the coefficient of variation of the two portfolios have been obtained, to proof that there is a difference between the two portfolios, thus independent sample t-test was used. Independent sample t-test was used to proof that there is a difference between two uncorrelated population samples. In order to conduct independent sample t-test, SPSS 22 Software was used.

\subsection{Normality Test}

Normality test is needed to conduct classic assumption test. Normality test was used to test the normal distribution of the tested data. In this research, Kolmogorov-Smirnov normality test was used with significance level $(\alpha)$ of $5 \%$. If the data's significance is $>$ 0,05 , thus the data is distributed normally, if it is $<0,05$, the the data is not distributed normally. 


\subsection{Hypothesis Test}

To proof whether there is a significant difference in the performance of the portfolios of stocks registered and unregistered in LQ45 Index, thus the values of coefficient of variation of the two portfolios were compared against one another. The difference was tested using independent sample t-test. This test was used to find out the difference between the two populations samples that are not related. The formula used is as follows:

$$
t=\frac{X_{1}-X_{2}}{\sqrt{\left(\frac{S_{1}^{2}}{n_{1}}\right)+\left(\frac{S_{2}^{2}}{n_{2}}\right)}}
$$

Where,

$$
\begin{aligned}
& X_{1}=\text { Mean of Group } 1 \\
& X_{2}=\text { Mean of Group } 2 \\
& S_{1}=\text { Standard deviation of Group } 1 \\
& S_{2}=\text { Standard deviation of Group } 2 \\
& n_{1}=\text { The number of samples in Group } 1 \\
& n_{2}=\text { The number of samples in Group } 2
\end{aligned}
$$

\section{Result and Discussion}

\subsection{Building an Optimal Portofolio}

In building a portfolio, the return and risk of the stocks of the selected companies included in the portfolio are needed. In this research, the returns and risks of the stocks that form the portfolio are included. The result of return and risk calculations of stocks registered in LQ45 Index are as follows:

Based on Table 1, it shows that the highest return was by PT. Adaro Energy Tbk's stock. (ADRO), which was approximately 0,6279. It shows that the mean of ADRO's annual return within the period of 2015-2017 was 0,6279. The lowest stock return was by PT. Sawit Sumbermas Sarana Tbk. (SSMS), which was approximately $-0,0132$. This shows that the mean of SSMS's annual return within the period of 2015-2017 was 0,0132. The lowest risk shown in Table 1 was PT. Telekomunikasi Tbk's (TLKM) stock. TLKM had the lowest risk, which was approximately 0,0354. Based on Table 1, it shows that PT. Adaro Energy Tbk. (ADRO) had the highest risk, which was 0,4905. Whereas, 
TABLE 1: Return and Risk of Stocks Registered in LQ45 Index.

\begin{tabular}{l|c|c|}
\hline Stocks & Return & Risk \\
\hline SSMS & $-0,0132$ & 0,0794 \\
\hline ADRO & 0,6279 & 0,4905 \\
\hline INTP & 0,0027 & 0,1266 \\
\hline ASII & 0,0634 & 0,0968 \\
\hline UNVR & 0,2116 & 0,0681 \\
\hline WSKT & 0,1766 & 0,1107 \\
\hline TLKM & 0,1604 & 0,0354 \\
\hline BBTN & 0,4900 & 0,1682 \\
\hline UNTR & 0,2988 & 0,1156 \\
\hline
\end{tabular}

Source: Processed Data, 2018

the returns and risks of stocks unregistered in LQ45 Index within the period of 2015-2017 are as follows:

TABLE 2: Return and Risk of Stocks Unregistered in LQ45 Index 5.

\begin{tabular}{l|c|c|}
\hline Stocks & Return & Risk \\
\hline BISI & 0,3537 & 0,1283 \\
\hline PTRO & 0,7006 & 0,4015 \\
\hline SMBR & 2,9045 & 1,6436 \\
\hline KRAH & 0,6489 & 0,3049 \\
\hline INAF & 8,8637 & 5,1959 \\
\hline MKPI & 0,3488 & 0,0732 \\
\hline INDY & 2,6551 & 1,0510 \\
\hline BJBR & 1,0774 & 0,6986 \\
\hline MIDI & 0,2227 & 0,0535 \\
\hline
\end{tabular}

Source: Processed Data, 2018

The highest return from stocks unregistered in the LQ45 Index within the period of 2015-2017 was by PT. Indofarma Tbk. (INAF), which was approximately 8,8637 . The lowest return was by PT. Midi Utama Indonesia Tbk. (MIDI), which was 0,2227. Based on Table 2, the lowest risk was by PT. Midi Utama Indonesia Tbk. (MIDI), which was 0,0535. The highest risk was by PT. Indofarma Tbk. (INAF) approximately 5,1959.

After the portfolio was built, there were 8 optimal portfolios from the two stock categories. Below is the optimal portfolio of stocks registered in LQ45 Index: 
TABLE 3: Optimal Portofolio of Stocks Registered in LQ45 Index.

\begin{tabular}{|l|c|c|c|}
\hline Portofolio & Return & Risk & $\begin{array}{c}\text { Coefficient of } \\
\text { Variation }\end{array}$ \\
\hline 1 & 4,7313 & 0,0018 & 0,0004 \\
\hline 2 & 6,5313 & 1,5483 & 0,2371 \\
\hline 3 & 8,3312 & 3,5224 & 0,4228 \\
\hline 4 & 10,1312 & 5,5090 & 0,5438 \\
\hline 5 & 11,9312 & 7,7452 & 0,6492 \\
\hline 6 & 13,7312 & 10,5784 & 0,7704 \\
\hline 7 & 15,5312 & 13,4116 & 0,8635 \\
\hline 8 & 17,3311 & 16,5342 & 0,9540 \\
\hline
\end{tabular}

Source: Processed Data, 2018

In this research, the portfolios' performances were measured using coefficient of variation. Coefficient of variation is a ratio of the value of risk divided by the expected return. The higher the coefficient of variation, the worse the portfolio's performance. The lower the coefficient of variation, the better the portfolio's performance. An optimal portfolio from stocks unregistered in LQ45 Index within the period of 2015-2017 is as follows:

TABLE 4: Optimal Portofolio of Stocks Unregistered in LQ45 Index.

\begin{tabular}{|l|c|c|c|}
\hline Portofolio & Return & Risk & $\begin{array}{c}\text { Coefficient of } \\
\text { Variation }\end{array}$ \\
\hline 1 & 82,2633 & 88,0320 & 1,0701 \\
\hline 2 & 112,7193 & 144,8053 & 1,2847 \\
\hline 3 & 143,1757 & 203,0480 & 1,4182 \\
\hline 4 & 173,6317 & 264,4700 & 1,5232 \\
\hline 5 & 204,0880 & 327,3790 & 1,6041 \\
\hline 6 & 234,5440 & 391,0567 & 1,6673 \\
\hline 7 & 265,0000 & 455,1833 & 1,7177 \\
\hline 8 & 295,4563 & 519,5933 & 1,7586 \\
\hline
\end{tabular}

Source: Processed Data, 2018

After coefficient of variation for each portfolio has been calculated, the mean difference test. The mean difference test used in this research was independent sample t-test. Independent sample t-test is used to proof the difference between two unrelated population samples, which were population of portfolio consisting stocks registered in LQ45 Index and portfolio consisting stocks unregistered in LQ45 Index. The assumptions that 
need to be fulfilled in the independent sample t-test are the data must be distributed normally, there is no outlier, and the variance among the groups is homogeny.

\subsection{Normality Test}

In order to test whether the data is distributed normally, Shapiro Wilk and Liliefors tests were conducted using SPSS 22 Software. The confidence level in this research was $95 \%$. If the significance value $>0.05$, according to Shapiro Wilk and Liliefors tests, the data is distributed normally. The result of the calculation using SPSS 22 is as follows:

TABLE 5: Normality Test.

\begin{tabular}{l|cc|cc} 
Category & \multicolumn{2}{c|}{ Liliefors } & \multicolumn{2}{c}{ Shapiro-Wilk } \\
\hline & Statistic & Sig. & Statistic & Sig. \\
\hline LQ45 & 0.122 & 0.200 & 0.963 & 0.841 \\
\hline Non LQ45 & 0.162 & 0.200 & 0.925 & 0.476 \\
\hline
\end{tabular}

Source: Processed Data, 2018

Based on Table 5, it is shown that the Liliefors significance value from the two portfolios are 0.200 . The significance value is greater than 0.05 , thus, based on Liliefors test, the data for each group are distributed normally. The significance value of Shapiro Wilk of LQ45 group is 0.841 and non LQ45 group is 0.476 . Both groups' values are greater than 0.05 , thus, based on Shapiro Wilk test, the data of both groups are distributed normally. After normal distribution has been confirmed, next, homogeneity test was conducted using Levene test. The result of the homogeneity test is as follows:

TABLE 6: Homogeneity Test.
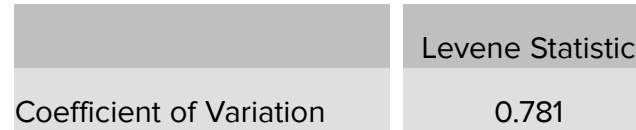

$$
\text { Sig. }
$$

Source: Processed Data, 2018

The value of Levene test is shown under "based on mean" row. Based on Table 6 , it is shown that the significance value is 0.392 . If the significance value is greater than 0.05 , thus there is a similarity within the variance of the groups, hence homogeny. The significance value is $0.392>0.05$, thus there is similarity or homogeny. After homogeneity test, the next step was to detect outliers, which can be seen in this figure below: 


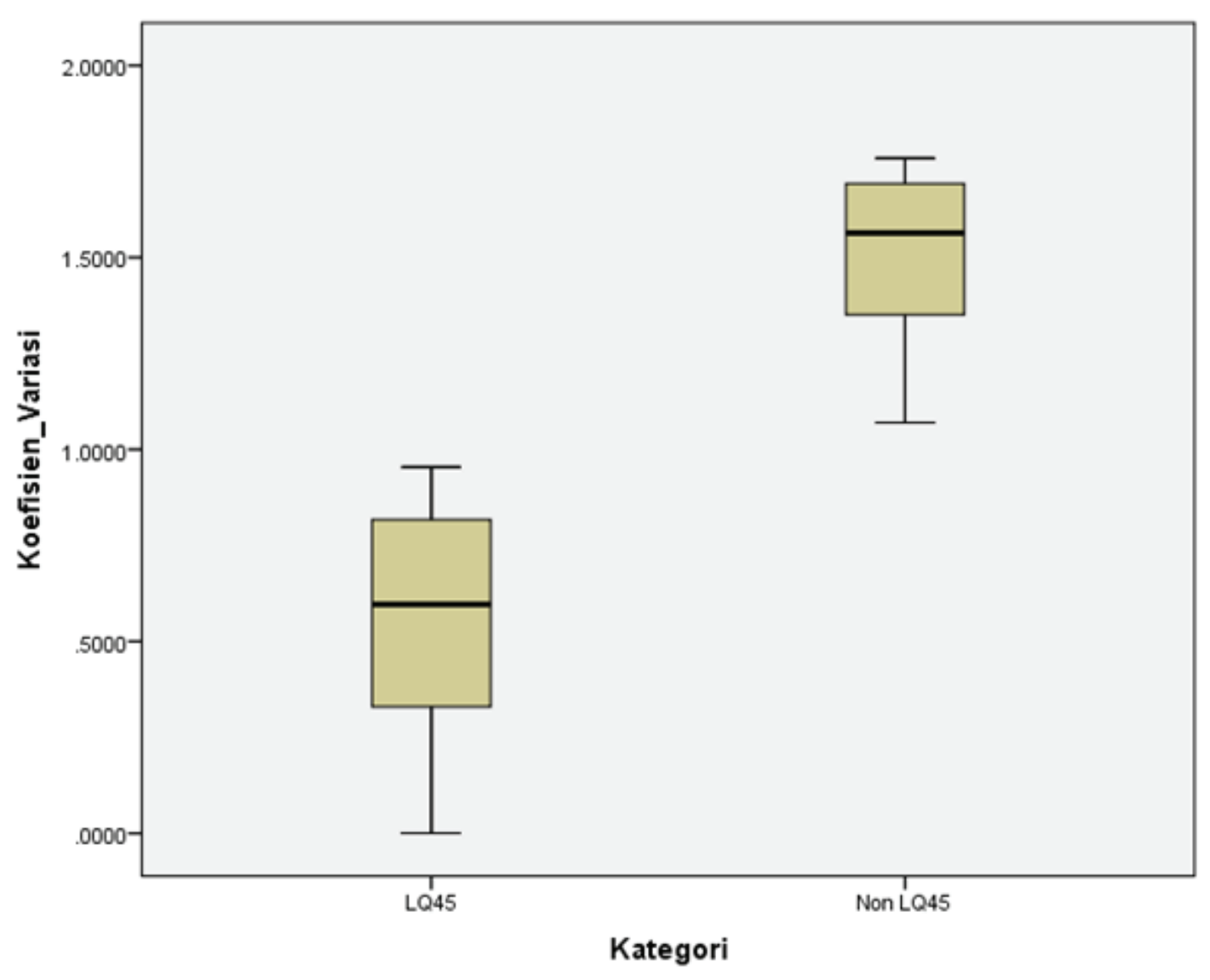

Figure 1: Detecting Outliers using Box-plot Method (Source: SPSS 22, 2018).

It can be seen from the figure above that there is no outlier. If there is data outside the candle, thus it is called an outlier. After all assumptions have been fulfilled, the next step was to conduct independent sample t-test.

\subsection{Hypothesis Test}

In order to proof that there is a significant difference between the two groups' portfolio performances, independent sample t-test was conducted. This test compared two groups of data that are not related. The result of the independent sample t-test is as follows:

To know whether there is a difference, it can be seen from the significance value. If the significance is lower than 0.05, there is a significant difference. Based on Table 7 , it is shown that the significance value is 0.000 , thus there is a significant difference between the two groups' portfolio performances. 
TABLE 7: The Result of Independent Sample t-test.
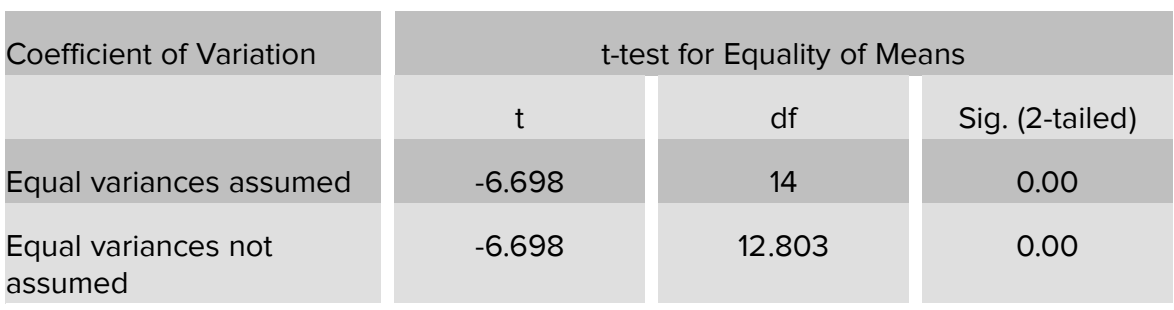

Source: Processed Data, 2018

\section{Conclusion}

Based on the conducted research, there are several conclusions to be drawn:

1. Return of portfolio consisting stocks registered in LQ45 Index is lower than return of portfolio consisting stocks unregistered in LQ45 Index. Risks of portfolio consisting stocks registered in LQ45 Index is lower than risks of portfolio consisting stocks unregistered in LQ45 Index. Based on the coefficient of variation, portfolio consisting stocks registered in LQ45 Index is relatively lower than portfolio consisting stocks unregistered in LQ45 Index. The lower the coefficient of variation, the better the performance of the portfolio.

2. The conducted hypothesis test stated that there is a significant difference between the two groups of portfolios. Therefore, there is a significant difference between portfolio consisting stocks registered in LQ45 Index and portfolio consisting stocks unregistered in LQ45 Index within the period of 2015-2017.

\section{Acknowledgements}

This research was supported by Universitas Ciputra, Indonesia. The researchers want to thank to Universitas Ciputra, Indonesia. The researcher also thanked all parties who were involved so that this research could be completed well.

\section{References}

[1] Amalia, D. A. dan Kartikasari, D. (2016). Analisis Perbandingan Kinerja Saham Perusahaan Manufaktur Terindeks Syariah dan Konvensional. Jurnal Akuntansi, Ekonomi dan Manajemen Bisnis, Vol. 4, No. 2, 128-135.

[2] Darmadji, T., dan Fakhruddin, H. M. (2012). Pasar Modal di Indonesia: Pendekatan Tanya Jawab. Edisi Ketiga. Jakarta: Salemba Empat. 
[3] Jogiyanto, H. (2009). Teori Portofolio dan Analisis Investasi. Edisi Keenam. Yogyakarta: BPFE.

[4] Natalia, E., Darminto, dan Endang, M. G. W. (2014). Penentuan Portofolio Saham yang Optimal dengan Model Markowitz Sebagai Dasar Penetapan Investasi Saham. Jurnal Administrasi Bisnis (JAB), Vol. 9, No. 1, 1-9.

[5] Prabowo, H. (2013). Analisis Portofolio Saham dengan Metode CAPM dan Markowitz. Binus Business Review, Vol. 4, No. 1, 360-369.

[6] Pracanda, D. G. S. P. dan Abudanti, N. (2017). Pembentukan Portofolio Optimal dengan Menggunakan Model Markowitz pada Saham Indeks IDX30 di Bursa Efek Indonesia. E-Jurnal Manajemen Unud, Vol. 6, No. 2, 802-829.

[7] Setiawan, S. (2017). Analisis Portofolio Optimal Saham-saham LQ45 Menggunakan Single Index Model di Bursa Efek Indonesia Periode 2013-2016. Journal of Accounting and Business Studies, Vol. 1, No. 2, 1-19.

[8] Tandelilin, E. (2010). Portofolio dan Investasi: Teroti dan Aplikasi. Edisi Pertama. Yogyakarta: Kanisius.

[9] Zubir, Z. (2013). Manajemen Portofolio: Penerapannya dalam Investasi Saham. Jakarta: Salemba Empat. 